from several laboratories and the method of in Britain and the relatively low exposure Prince. ${ }^{4}$

$484(6.05 \%)$ of the donors were carriers of $\mathrm{Au}(1)$, while $13(0.16 \%)$ had the antibody. There was a monthly variation in the prevalence of $\mathrm{Au}(1)$ antigenaemia, varying from $3.8 \%$ in May to $10.1 \%$ in April (see Table). There was no correlation between the $\mathrm{Au}(1)$ carrier state and ABO blood group or haemoglobin genotype. Au(1) was prevalent in all age groups but commonest in the second and third decades.

Among 423 school children aged between 4 and 20 years who lived in two boarding house in Ibadan $\mathrm{Au}(1)$ was present in $29(6.7 \%)$ and the antibody in $1(0.24 \%)$. There were 208 giŕls and 215 boys in the study population; 11 $(5.3 \%)$ of the girls and $18(8.4 \%)$ of the boys had the antigen. The only student with antibody was a 17-year-old girl.

Details of this study will be published later. We are, etc.

T. I. FRANCIS J. A. SMITH

Departments of Medicine and Pathology,

University College Hospital,

1 Blumberg, B. S., Sutnick, A. I., London, W. T. and Millman, I, New England fournal of

Medicine and Hygiene, 1970, 19, 872. Tropical

Haematologica, 1969, 54, 591 .
Hedarida, Gonara, A., Prince, A. M., Proceedings

Academy of Sciences, 1968, 60, 814 .

\section{Anticonvulsant Osteomalacia}

SIR,-Dr. John Hunter and others (23 October, p. 202) confirmed in children our finding 1 in adult epileptics that calcium metabolism is disturbed by anticonvulsant therapy. Although we agree with them that the most likely cause of this disturbance is altered vitamin $\mathbf{D}$ metabolism in the liver, the evidence which they present goes little further to prove an aetiological relationship between liver enzyme induction and abnormal calcium metabolism than former evidence allowed. Indeed, the inverse correlation which they have shown between serum calcium levels and urinary glucaric acid excretion was to be expected, for they had previously found ${ }^{2}$ a correlation between total daily dose of anticonvulsant drugs and urinary glucaric acid excretion, while we had shown ${ }^{1}$ an inverse correlation between total daily dose and serum calcium levels. It follows, therefore, that glucaric acid excretion should inversely correlate with serum calcium. This does not necessarily imply an aetiological relationship, for if both phenomena are drug induced and dose related a correlation is only to be expected. However, disturbed vitamin D metabolism is the most attractive theory to explain the calcium abnormalities, and has recently been given support by the finding ${ }^{3}$ that phenobarbitone treatment shortens the half-life of tritiated cholecalciferol in man, leading to accumulation of more polar, inactive products in the serum. In addition, the liver microsomes of phenobarbitone-pretreated rats were found in vitro to rapidly convert cholecalciferol to metabolites other than the active metabolite. 25-hydroxycholecalciferol, whereas no significant conversion could be demonstrated in the microsomes of control rats.

The suggestion by Dr. Hunter and others that an increased demand for vitamin D produced in these patients by drug treatment can precipitáte deficiency, given the relatively low dietary intake of the vitamin to sunlight seems to us an eminently reasonable one. We have looked at this point by dividing the patients who were included in our survey ${ }^{1}$ into two groups according to their daily work at the Chalfont Centre. Of the 26 patients who had been working in the farm and farm gardens during the year before our survey only $2(8 \%)$ had low serum calcium levels, whereas of the 102 who had been engaged in indoor work $26(25 \%)$ had abnormal calcium levels. The mean serum calcium $( \pm \mathrm{SE})$ of the former group was $9.48 \pm 0.08 \mathrm{mg} / 100 \mathrm{ml}$ and that of the latte group was $9 \cdot 18 \pm 0 \cdot 04$. The difference between these is significant ( $t$ test, $P<0.005$ ).

While, however, exposure to sunlight is obviously important we consider it importan only in so far as it increases the production of vitamin D in patients working outdoors and so makes them less likely to develop a drug-induced deficiency. In the absence of anticonvulsant drug treatment all these patients, whether working indoors or outdoors, would be expected to have an adequate production and intake of the vitamin. It has been stated earlier ${ }^{1}$ that the diet of the patients was considered to be adequate in terms of its vitamin $\mathbf{D}$ content A subsequent assessment of this has indicated that their daily intake was 75 I.U. on average, which compares favourably with the intake in some areas of Britain. ${ }^{4}-W e$ are, etc.,

Department of Clinical Pharmacology, t. Bartholomew's Hospital, ondon E.C.1

Metabolic Ward, University College Hospital,

Richens, A., and Rowe, D. J. F., British Medical Fournal, 1970, 4.73.

Hunter, J., Maxwell, J. D., Carrella, M., Stewart, D. A. and Williams, R., Lancet, 1971, 1, 572 Avioli, L. V. Clinical Research, 1971, 19, 50 Lumb, G. A., Mawer, E. B., and Stanhury, S. W American fournal of Medicine, 1971, 50, 421.

\section{Responsibility of the Scientist}

SIR,-The wise letter from Dr. S. Bradshaw (27 November, p. 557) concerning Sir George Pickering's paper (16 October, $p$. 131) must reflect the opinions of many practitioners and consultants.

It has been disturbing to read the views of many physicians whom we have regarded as eminent, putting "the care of the patient" second to research and investigation. Of course the latter are important to the whole approach but we must keep our priorities right in teaching medicine and nursing to students, otherwise the patient will suffer. -I am, etc.

Leighton Buzzard,

JOHN T. INGRAM

\section{Dichloralphenazone and Breast Milk}

SIR,-The decision to give drugs to nursing mothers is particularly difficult, for not only has the mother to be considered but also the effect the drug may have on the infant if the drug is secreted in breast milk. This note reports our measurement of dichloralphenazone in the blood and milk of a lactating neurotic mother with severe tension by day and insomnia at night. It was to allay these that we began modified narcosis with chlorpromazine and dichloralphenazone.
The patient was a 20-year-old depressed girl with very severe symptoms since the birth of her child five months before her admission. She had wanted to breast-feed the infant and so was encouraged to continue in the belief that this would aid her recovery. She was physically normal. She was given chlorpromazine $100 \mathrm{mg}$ t.d.s. and dichloralphenazone $1,300 \mathrm{mg}$ in the evening. The feeding schedule that she had herself established was unaltered in that the child was breast-fed at 0800,1500 , and 2100 , with a supplementary feed at 1300. Milk, by expression, and blood samples were taken just before each breast feed. The child was weighed before and after feeds to find the weight of milk supplied and from this the volume of milk determined.

In the body dichloralphenazone is reduced to trichlorethylalcohol, which produces the central depressant effect. ${ }^{12}$ The trichlorethanol was measured in samples of breast milk and maternal and infant blood plasma by Mr. D. J. Berry of the Poisons Reference Service, using a sensitive gas chromatographic method. The results are shown in the Table.

TABLE-Trichlorethanol Level $(\mathrm{mg} / 100 \mathrm{ml})$ of Maternal Plasma and Milk after $1,300 \mathrm{mg}$ of dichloralphenazone at 2200

\begin{tabular}{l|l|l|l}
\hline Date & Time & Plasma & Milk \\
\hline 14 July & 1700 & $0 \cdot 15$ & $0 \cdot 12$ \\
& 2100 & $0 \cdot 14$ & $0 \cdot 10$ \\
15 July & 0800 & $0 \cdot 34$ & $0 \cdot 27(0730)$ \\
& 1700 & $0 \cdot 18$ & $0 \cdot 12$ \\
16 July & 2100 & $0 \cdot 13$ & $0 \cdot 08$ \\
& 0800 & $0 \cdot 32$ & $0 \cdot 25(0730)$ \\
& 1700 & $0 \cdot 18$ & $0 \cdot 11$
\end{tabular}

No trichlorethanol was detected in the plasma of the baby at 1800 on 15 July 1971. No chlorpromazine was found in either the patient's milk or serum. The limit of detection of chlorpromazine by this method is $0.05 \mathrm{mg} / 100 \mathrm{ml}$ so that she must have been secreting less than that. We can expect this from the results of other workers. ${ }^{34}$ It will be noticed that the concentration of trichlorethanol in milk reflected that in the plasma, an observation similar to that found with other drugs. The concentration of trichlorethanol in the milk was between 0.6 and 0.8 of that in the plasma, a figure higher than that reported for chlorpromazine. ${ }^{3}$

We found the levels obtained at particular times each day corresponded well with each other, and as might be expected the higher concentrations occurred in the morning. The highest concentration in milk was $0.27 \mathrm{mg} / 100 \mathrm{ml}$, which would have resulted in the infant imbibing $40.50 \mathrm{mg}$ of trichlorethanol during its maximum feed $(150 \mathrm{ml})$. The infant's growth, activity, and development during this period were normal except that the infant appeared minimally more drowsy during the early morning. Three months after the drug was stopped the baby is still well.-I am, etc.,

Department of Psychiatry,

J. H. L.ACEY St. George's Hospital,
Tooting, London S.w.17 1 Burler, T. C. Fournal of Pharmacology and Ex-
berimental Therabeutics, 1948, 92, 49.
2 Marshall. E. K. and Owens, A. H., Bulletin of Marshall. E. K., and Owens, A. H., Bulletin of
the Fohns Hopkins Hospital. 1954, 95. 1. Blacker, K. H., Weinstein, G. H.. and Ellman,
G. L., American fournal of Psychiarty, 1962/3, 119. 178 .

4 Ayd, F. J., Clinical Medicine, 1964, 71, 1758. 